\title{
Estimates of kinetic degradability parameters and passage of materials originated from intercropping of brachiaria grass and corn and soybean crops
}

\author{
Tadeu Silva de Oliveira ${ }^{1}$, José Carlos Pereira ${ }^{2}$, Ricardo Augusto Mendonça Vieira ${ }^{3}$, Fernando \\ de Paula Leonel ${ }^{4}$, Marcelo Teixeira Rodrigues ${ }^{2}$
}

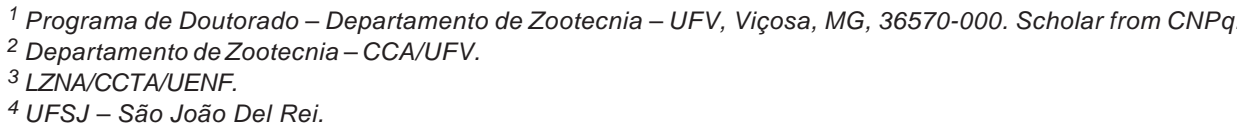

ABSTRACT - The study was conducted to determine the kinetic parameters of in situ DM and NDF and the passage of particles of forages produced from the intercropping of brachiaria grass with corn and soybean crops. Three experiments were performed, as follows: Experiment 1 - Brachiaria grass intercropped with corn at different plant ages; Experiment 2 Cultivation of brachiaria grass intercropped with corn set in different sowing arrangements; and Experiment 3 - Intercropping of brachiaria grass and soybean. Passage kinetic of particles was determined by the recovery of markers in feces. In order to obtain the ruminal degradation of DM and NDF, nylon bags were used at zero time, 3, 6, 9, 12, 24, 48, 72, 96, 120 and 144 hours. The particles' passage kinetic of corn with brachiaria grass silage and brachiaria grass silage presented $3 \% / \mathrm{h}$ and $2.3 \% / \mathrm{h}$, respectively; and for soybean and brachiaria grass silage, it was $1.8 \%$ /h, which can be explained in part by the mixture of materials ensiled. The materials originated from the intercropping caused rumen fill. Degradation rates were lower when compared with literature data. The brachiaria grass silage obtained from corn and/or soybean crop-pasture integrated system is a feed with low nutritive value due to its low NDF degradation rate and low passage rate, causing rumen fill and, thus, possibly resulting in low intake and poor animal performance.

Key Words: digestion kinetics, Fabaceae, passage rate, Poaceae

\section{Introduction}

The feeds' capacity of supplying nutrients to animals is a characteristic intrinsic of the feedstuff itself, which depends on the degradation extension and the rate of passage through the gastrointestinal tract, which determine, on the one hand, the quality of the substrate that may be absorbed in digestion and, on the other hand, condition the amount of feed that can be ingested by the animal.

In Brazil, pasture constitutes the basis of the feed of the ruminants and, generally, it is characterized by its high fiber content, which is very important, since its components are related to digestibility, rumen fermentation and energy value of the feed - factors that are directly connected to animal productivity. The neutral detergent fiber (NDF) is the main energy substrate to animals that feed on roughagebased diets, and can be subdivided into an indigestible fraction and another potentially digestible.

In the practice of managing areas, usually called croplivestock integration, the shading generated by a certain corn crop on the pasture, for instance, may alter the profile of the fiber, affecting mainly the cell wall, with reduction of the photoassimilates used for the development of the secondary cell wall, due to the decrease in light absorption.

In the literature, there are studies presenting results in which the crop-livestock integration system generates improvement of the nutritional value of the forage and digestibility. Samarakoon et al. (1990), Kephart \& Buxton (1993) and Paciullo et al. (2007) verified increase in the fiber content and digestibility of shadowed plants. However, results from other studies proved that, in this system, there is increase in lignin and silica content in shadowed plants (Castro et al., 1999); and others indicate that the dry matter (DM) digestibility of forage decreases with reduction of light intensity (Masuda, 1977; Castro et al., 1999).

Therefore, there are contradictions in this topic, hence the need for the conduction of further research. In regard of that, the objective of this study is to determine the kinetic parameters of in situ degradability of DM and NDF and the passage of materials originated from the intercropping between brachiaria grass and corn or soybean crops. 


\section{Material and Methods}

This study was conducted at the Departamento de Zootecnia of the Universidade Federal de Viçosa, in the municipality of Viçosa, Minas Gerais. Coordinates are $20^{\circ} 45^{\prime} 14$ " S; 42 ${ }^{\circ} 52^{\prime} 53^{\prime \prime} \mathrm{W}$ and altitude of $648.74 \mathrm{~m}$.

The kinetic degradability parameters of rumen degradation and passage of particles in samples from three experiments conducted by Leonel (2007), at the Estação Experimental of Departamento de Fitotecnia of the Universidade Federal de Viçosa, in the municipality of Coimbra, Minas Gerais, related to the intercropping between brachiaria grass and corn or soybean crops.

In experiment 1 , the kinetic degradability of rumen and particles' passage of silages of corn intercropped with brachiaria grass at different plant ages was determined. Corn and brachiaria grass were established by direct seeding, followed by a degraded pasture of molasses grass (Melinis minutiflora). Liming and fertilization were performed according to soil analysis, following the basic recommendations for corn cultivation.

For the planting of corn (AG122), the seeder was set to obtain a plant population of 50,000 plants/ha ${ }^{-1}$. For the forage, by means of seeder adaptation, sowing was done in between the rows or on the rows, with density of $3 \mathrm{~kg} / \mathrm{ha}^{-1}$ of pure viable seeds of Urochloa brizantha cv. MG5.

The proportion between the mass of corn forage and brachiaria grass was of 92:8, i.e., close to a 9:1 relation.

Ensiling of the materials originated from the intercropping between corn and brachiaria grass was performed with plants at different ages: 100 days post-planting (corn ensiling point); 120 days post-planting; 140 days postplanting; and 160 days post-planting, represented by CEP, 20D, 40D and 60D, respectively.

At the experiment, kinetics of rumen degradation and passage of particles of corn intercropped with brachiaria grass with different seeding arrangements were determined. Corn and brachiaria grass cultivations were established like in experiment 1 , defining the following seeding arrangements between the cultivations: $\mathrm{BEC}=$ brachiaria grass in exclusive cultivation; $\mathrm{CEC}=$ corn in exclusive cultivation; $\mathrm{C}+2$ brachrow $=$ seeding of two rows of brachiaria grass in between the corn rows; and C + Bhand = broadcast hand-sowing of brachiaria grass in between the corn rows.

The proportion of corn forage mass and brachiaria grass mass in arrangement $\mathrm{C}+2$ brachrow was 92:8, i.e., close to a 9:1 relation; for corn and brachiaria grass in arrangement $\mathrm{C}+$ Bhand it was 98:2; for corn in exclusive cultivation, $40.58 \mathrm{t} / \mathrm{ha}$; and for brachiaria grass in exclusive cultivation it was $12.158 \mathrm{t} / \mathrm{ha}$.
In experiment 3 , kinetics of rumen degradation and passage of particles of corn intercropped with brachiaria grass were determined. Soybean and brachiaria grass were established by direct planting, and liming and fertilization were performed according to soil analysis, following the basic recommendations for soybean cultivation.

Soybean variety was Pioneer DM 339 and fertilization and cultivation followed the crop management under exclusive cultivation. Forage was established by means of seeder adaptation, and sowing was performed in between the soybean rows, with density of $3 \mathrm{~kg} / \mathrm{ha}^{-1}$ of pure viable seeds of Urochloa brizantha cv. Marandu.

Evaluations were done in two different stages of soybean maturation: at point R6 (full pod-filling) and R7 (start of maturation of seeds and $50 \%$ of yellowish foliation) according to Ferh \& Caviness' (1977) classification, with brachiaria grass in exclusive cultivation harvested according to the soybean maturation stages.

The proportion between the forage masses of brachiaria grass and soybean was 50.23:49.77; close to 1:1, with following ensiling: brachiaria grass in exclusive cultivation (at point R6); brachiaria grass in exclusive cultivation (at point R7); silages of soybean and brachiaria grass at maturation point R6; silages of soybean and brachiaria grass at maturation point R7.

In order to determine the parameters related to kinetics of passage of particles, lanthanum (La) markers were used for the samples of silages of corn with brachiaria grass according to methodology by Hartnell \& Statter (1979), and ytterbium $(\mathrm{Yb})$ markers were used for the samples of silages of brachiaria grass with soybean, following technique proposed by Ellis \& Beever (1984). For samples of brachiaria grass in exclusive cultivation, sodium dichromate was used, forming Cr-NDF or "Chrome mordant", according to methodology described by Udén et al. (1980). The samples marked were obtained by means of composite sampling of the respective materials.

Animals received $100 \mathrm{~g}$ of each silage marked with the respective indicators by means of rumen cannula. Approximately $200 \mathrm{~g}$ of feces were collected at the following times: zero time (right after administration of feed marked), 4, 8, 12, 16, 24, 30, 36, 48, 72, 96 and 120 hours.

The content of chrome in the feces was dosed according to the methodology described by Williams et al. (1962). The preparation of samples for determination of Yb content followed the methodology described by Moore et al. (1992). $\mathrm{La}$ and Yb's analysis was performed in atomic absorption spectrophotometer, nitrous oxide-acetylene flame with wavelength of $\lambda=398.8 \mathrm{~nm}$ and slit aperture of $0.2 \mathrm{~nm}$, according to Huhtanen \& Givens (1995). 
The parameters of particle passage kinetics were estimated by means of bicompartimental model, as proposed by Matis (1972):

$C(t)=C_{0} k_{e}\left\{\delta^{N_{r}} e^{-k_{e}(t-\tau)}-e^{-\lambda_{r}(t-\tau)} \sum_{i=1}^{N_{r}} \delta^{i} \frac{\left[\lambda_{r}(t-\tau)\right]^{N_{r}-i}}{\left(N_{r}-i\right) !}\right\}$ in which: $\mathrm{C}(\mathrm{t})=$ concentration of the indicator in fecal dry matter, in $\mathrm{mg} / \mathrm{kg} ; \mathrm{C}(0)=$ initial concentration of the indicator in the raft $(\mathrm{mg} / \mathrm{kg}) ; \lambda \mathrm{r}\left(\mathrm{h}^{-1}\right)=$ rate of the transfer of particles marked by the raft indicator for the pool of escapable particles; ke $\left(\mathrm{h}^{-1}\right)=$ rate of escape of the pool of escapable particles marked with rumen indicator to the rest of the gastrointestinal tract; $\mathrm{t}(\mathrm{h})=$ time after supply of the indicator; $\tau=$ time of passage of the indicator from its leaving from the reticulo-omasal orifice to the appearing in feces; $\mathrm{Nr}=$ order of time dependence.

$$
\delta=\frac{\lambda_{r}}{\lambda_{r}+k_{e}}
$$

The $k p\left(h^{-1}\right)$ corresponding to the rate of the passage of the digesta in the rumen-reticulum was calculated according to the expression: 1/MTR-RR, in which MTR-RR (mean time of retention in the rumen-reticulum) was obtained by the expression:

\section{MTR-RR $=\mathrm{Nr} / \lambda \mathrm{r}+1 / \mathrm{ke}$}

Rumen fill (RF) of fiber was determined by utilizing the equation of Vieira et al. (2008):

$$
\begin{aligned}
& \mathrm{RR}=\mathrm{A}_{\text {ndf }}\left\{\sum_{\mathrm{i}=1}^{\mathrm{Nr}}\left[\lambda_{\mathrm{r}}^{\mathrm{i}-1} /\left(\lambda_{\mathrm{r}}+\mathrm{kd}\right)^{\mathrm{i}}\right]+\lambda_{\mathrm{r}}^{\mathrm{Nr}} /\left[\left(\lambda_{\mathrm{r}}+\mathrm{kd}\right)^{\mathrm{Nr}}(\mathrm{ke}+\mathrm{kd})\right]\right\}+ \\
& \left.+\mathrm{U}_{\text {ndf }}\left[\mathrm{N}_{\mathrm{r}} / \lambda_{\mathrm{r}}+1 / \mathrm{ke}\right]\right\}
\end{aligned}
$$

in which: $A_{\text {ndf }}=$ soluble fraction of the neutral detergent fiber; $\mathrm{U}_{\text {ndf }}=$ undegradable fraction of neutral detergent fiber; $k d$ = rate of degradation of the potentially digestible fraction of fiber in the rumen.

For determination of the rumen kinetic parameters of DM and NDF of silages, the in situ technique was adopted, as described by Mehrez \& Ørskov (1977) and Nocek (1985), by utilizing nylon bags with dimensions $13 \times 7 \mathrm{~cm}$ and pore size of $50 \mathrm{~mm}$, keeping a relation of $25 \mathrm{mg} \mathrm{DM} / \mathrm{cm}^{2}$ of bag surface, according to recommendations of Kirkpatrick \& Kennelly (1987).

Incubation times were $0,3,6,9,12,24,48,72,96,120$ and 144 hours. After removed, bags were washed in running water until clearing, dried at $60 \pm 5^{\circ} \mathrm{C}$ in forced ventilation oven for 48 hours, and then taken to the dissector. Afterwards, respective weights were measured. Bags corresponding to time zero were not incubated in the rumen, despite being washed with all the others.

Bags were tied to the links of a chain in a sequence form (rows), immersed in the rumen contents, and the chain was anchored to the cannula. After, they were washed together in a container with running water, until the water presented no signs of residues of rumen contents. Next, they were taken to forced ventilation oven at $60 \pm 5{ }^{\circ} \mathrm{C}$ for 48 hours, and their dry weight was determined by analytical balance, with 0.1-mg approximation.

Residues were ground in a Willey mill provided with 1-mm diameter sieve, for determination of NDF.

The percentage of disappearance of DM and NDF at each incubation time was calculated by the proportion of feed retained in the bags after incubation in the rumen. Estimates of kinetic parameters of DM and NDF degradation were determined by the model of Mertens \& Loften (1980): $\mathrm{R}(\mathrm{t})=[\mathrm{R}(0)-\mathrm{U}] \mathrm{e}^{-\mathrm{kd}(\mathrm{t}-\mathrm{L})}+\mathrm{U}+\mathrm{e} ; \mathrm{t}>\mathrm{L}$

in which: $\mathrm{R}=$ residue post-incubation $\mathrm{R}(\mathrm{t})$; $\mathrm{U}=$ indigestible fraction; $\mathrm{t}$ = incubation time; $\mathrm{L}$ = discrete latency period; $\mathrm{kd}=$ rate of degradation of the potentially digestible fraction of the fiber in the rumen; $\mathrm{R}(0)=$ residue of incubation at zero time.

The effective degradability (ED) of DM and NDF in the rumen was calculated utilizing the model proposed by Vieira et al. (2008):

$$
\mathrm{ED}=\mathrm{kd}\left\{\mathrm{v} \sum_{\mathrm{i}=1}^{\mathrm{Nr}}\left[\lambda_{\mathrm{r}}^{\mathrm{i}-1} /\left(\lambda_{\mathrm{r}}+\mathrm{kd}\right)^{\mathrm{i}}\right]+\lambda_{\mathrm{r}}^{\mathrm{Nr}} /\left[\left(\lambda_{\mathrm{r}}+\mathrm{kd}\right)^{\mathrm{Nr}}(\mathrm{ke}+\mathrm{kd})\right]\right\}
$$

in which: $\mathrm{kd}=$ degradation rate; $\lambda \mathrm{r}\left(\mathrm{h}^{-1}\right)$ rate of transfer of the particles marked by the raft indicator to the pool of escapable particles; $\mathrm{Nr}=$ order of time dependence.

The iterative process of the Marquadt algorithm was implemented in the PROC NLIN procedure of SAS (Statistical Analysis System, 1999), discussed in a comparative form.

\section{Results and Discussion}

Passage rates varied for silages, with values of $3 \% /$ hour for the silage of corn with brachiaria grass (SCB); $2.3 \%$ /hour for the silage of brachiaria grass (BG); and 1.8\%/hour for the silage of soybean with brachiaria grass (SSB) (Table 1).

The rate of passage of particles through the rumen is a variable of great importance, once it determines the flow of digesta through the digestive tract. In the case of tropical forages, the values are considered low, especially due to the high fiber content (Soares, 2002).

The main value found for the rate of passage of corn silage particles was 3\%/hour, close to the $3.2 \%$ /hour found by Martins et al. (2006).

For SSB, the passage rate was $1.8 \%$, a value that can be considered low if compared with the $5.5 \%$ /hour found by Rigueira (2007) for the silage of soybean in exclusive cultivation. Thus, one can infer that this low passage rate can be justified, partly, by the mixing of ensiled materials (soybean and brachiaria grass), which, according to Leonel et al. (2008), contains higher fiber content and lower protein 
Table 1 - Kinetics of passage of particles of brachiaria grass and corn; brachiaria grass; brachiaria grass and soybean silages

\begin{tabular}{|c|c|c|c|}
\hline \multirow[t]{2}{*}{ Item } & \multicolumn{3}{|c|}{ Silage } \\
\hline & Brachiaria grass and corn & Brachiaria grass & Brachiaria grass and soybean \\
\hline MRT-GIT, h & 41.246 & 48.246 & 62.716 \\
\hline $\mathrm{kp}, \mathrm{h}^{-1}$ & 0.030 & 0.023 & 0.018 \\
\hline $\mathrm{kd}, \mathrm{h}^{-1}$ & 0.018 & 0.0353 & 0.021 \\
\hline ke, $h^{-1}$ & 0.051 & 0.0345 & 0.0272 \\
\hline $\mathrm{C}(0), \mathrm{mg} / \mathrm{kg}$ & 0.3173 & 51.92 & 7229.9 \\
\hline $\mathrm{Nr}, \mathrm{h}^{-1}$ & 3 & 3 & 3 \\
\hline$\underline{\mathrm{Kr}, \mathrm{h}^{-1}}$ & 0.076 & 0.0783 & 0.056 \\
\hline
\end{tabular}

content in relation to the silage of soybean in exclusive cultivation.

The mean value of the passage rate of brachiaria grass particles was $2.3 \%$ /hour, close to that observed by Lira et al. (2006), of 2.9\%/hour. The low passage rate can reduce the efficiency of fermentation by increasing the expenses with bacterial maintenance and microbial recycling in the rumen, which inflict in less nitrogen and energy for the microbial growth (Waldo, 1986)

The time of retention in the rumen, calculated by the reciprocity of the passage rate in the organ ( $\mathrm{kp}$ ) is correlated with the level of animal feeding, for smaller intake result in lower passage rate, and, consequently, reduction in the supply of nutrients to the animal. Nevertheless, the rate of escape of the pool of particles marked with rumen indicator to the rest of the gastrointestinal tract for the corn intercropped with brachiaria grass was higher than for brachiaria grass and for the silage of soybean intercropped with brachiaria grass, generating higher passage rate.

The passage time (PT) and the mean retention time in the rumen-reticulum (MRT-RR) for the silage of corn intercropped with brachiaria grass were 8.4 and 41.24 hours, respectively, close to those found by Martins et al. (2006): 9.11 and 30.16 hours.

Henriques et al. (2001) evaluated the rate of the passage of corn in Holstein $\times$ Zebu cattle fed solely on this roughage and obtained MRT-RR values of 36.6 hours.

The mean retention time is an important variable in the studies on ruminant nutrition, especially when it comes to tropical forages, since it determines the retention of digesta by the gastrointestinal tract and influences the voluntary intake, which directly affects animal production, because it may limit the ingestion of nutrients.
Bigger amounts of forage in the diet increase the time of rumen retention due to the slower degradation rate of the fiber, and the presence of higher fiber content in the intestines reduces the time of post-ruminal retention by stimulating peristalsis. Shaver et al. (1988) and Ferreira et al. (1999) observed that the elevation in the fiber content in the bowls increased the post-ruminal peristalsis.

Data on the degradation rate of silages from the material originated from corn intercropped with brachiaria grass are scarce, which hampers comparisons. However, the degradation rates of silages of corn in exclusive cultivation were higher than those described by the Tabela Brasileira de Composição de Alimentos (Brazilian Chart of Foods Composition) (Valadares Filho et al., 2006), although this can be attributed to the higher NDF content of brachiaria grass intercropped with corn.

Tropical grasses, in spite of their high productivity, accumulate high concentration of cell wall throughout their growth cycle: a fraction of slow and incomplete digestion that occupies a lot of space in the gastrointestinal tract (Mertens, 1996) and causes variations at digestion, in addition to affecting the intake of feed (Van Soest, 1994; Mertens, 1996). Plant age at ensiling did not affect the soluble or potentially digestible fractions (Table 2).

In this study, the values of fraction B (Table 3) were close to the $64 \%$ cited on the Tabela Brasileira de Composição de Alimentos (Valadares Filho et al., 2006); a high value of undegradable fraction was observed in the samples of material ensiled 160 days after sowing, corresponding to 60 days after the corn ensilage point, which can be explained by the lignifications throughout the growth cycle of the plant. Rodrigues et al. (2004) suggest that the high fiber carbohydrate content of the cell wall and the lignin content of the forage are the main cause of lower degradability. 
Table 2 - Dry matter effective degradability of silages of corn intercropped with brachiaria grass at different plant ages

\begin{tabular}{lccccccc}
\hline Silage & \multicolumn{7}{c}{ Parameter } \\
\cline { 2 - 7 } & $\mathrm{A}(\%)$ & $\mathrm{B}(\%)$ & $\mathrm{U}(\%)$ & $\mathrm{L}\left(\mathrm{h}^{-1}\right)$ & $\mathrm{kd}\left(\mathrm{h}^{-1}\right)$ & ED (\%) & pdDMED $(\%)$ \\
\hline CEP & 25.18 & 57.19 & 17.63 & 0.23 & 0.0177 & 48.47 & 82.37 \\
20D & 23.3 & 52.22 & 24.48 & 0 & 0.0189 & 45.54 & 75.52 \\
40D & 20.89 & 52.12 & 26.99 & 0 & 0.0195 & 43.55 & 73.01 \\
60D & 28.8 & 56.14 & 15.06 & 0 & 0.006 & 38.50 & 84.94 \\
\hline
\end{tabular}

A = soluble fraction; $\mathrm{B}$ = potentially digestible fraction; $\mathrm{U}=$ undegradable fraction; $\mathrm{L}=$ latency period; $\mathrm{kd}=$ fractional rate of degradation; ED = effective degradation; pdDMED = potentially digestible dry matter effective degradation; CEP = corn ensiling point; $20 \mathrm{D}=20$ days after corn ensiling point; $40 \mathrm{D}=40$ days after corn ensiling point; $60 \mathrm{D}=60$ days after corn ensiling point.

Table 3 - NDF's effective degradability of silages of corn intercropped with brachiaria grass at different plant ages

\begin{tabular}{lccccc}
\hline Silage & \multicolumn{5}{c}{ Parameter } \\
\cline { 2 - 6 } & $\mathrm{B}(\%)$ & $\mathrm{U}(\%)$ & $\mathrm{L}\left(\mathrm{h}^{-1}\right)$ & $\mathrm{kd}\left(\mathrm{h}^{-1}\right)$ & $\mathrm{ED}(\%)$ \\
\hline CEP & 73.8 & 26.2 & 2.64 & 0.0175 & 29.82 \\
20D & 63.69 & 36.31 & 16.81 & 0.0265 & 33.51 \\
40D & 78.21 & 21.79 & 0.65 & 0.011 & 22.23 \\
60D & 49.9 & 50.1 & 18.48 & 0.017 & 19.84 \\
\hline
\end{tabular}

$\mathrm{B}=$ potentially digestible fraction; $\mathrm{U}=$ undegradable fraction; $\mathrm{L}=$ latency period; $\mathrm{kd}=$ fractional rate of degradation; $\mathrm{ED}=$ effective degradation; $\mathrm{CEP}=$ corn ensiling point; $20 \mathrm{D}=20$ days after corn ensiling point; $40 \mathrm{D}=40$ days after corn ensiling point; 60D $=60$ days after corn ensiling point.

The proportion of fiber carbohydrates of the cell wall and their lignin content are the factors which most affect the quality of tropical forages. According to Van Soest (1994), the NDF content of the foragesis negatively correlated to its intake, which is the variable with most influence on animal performance, once it affects the ingestion of all nutrients. Rodrigues \& Vieira (2006) also agree with this theory.

The effective dry matter degradability of the material originated from the intercropping was independent of the sowing arrangements (Table 4), although it was lower than the corn silage (63.54\%) cited on the Tabela Brasileira de Composição de Alimentos (Valadares Filho et al., 2006) and close to the values found by Carvalho et al. (2006), of $56.26 \%$, who worked with grasses degradation rate.

The undegradable fraction (U) of brachiaria grass was higher than the silage of corn intercropped with brachiaria grass, probably due to the higher number of corn ears at the moment of ensiling, once the ears have a high non-fiber carbohydrate content, causing a dilution effect, which is in agreement with the reports from Silva et al. (2006).

The degradation rate of NDF(Table 5 ) was below those found by corn silage's NDF $\left(0.0248 \mathrm{~h}^{-1}\right)$ on the Tabela Brasileira de Composição de Alimentos (Valadares Filho et al. 2006). However, SCB reached B values higher than that found on the same Table 5 for the corn silage (64\%), and brachiaria grass achieved a value close to the brachiaria grass described by these authors (67\%). NDF is one of the main components of the tropical roughages, presenting slow and incomplete digestion in the gastrointestinal tract of ruminants (Mertens, 1996). One can suggest that these compounds are the great factor for the low digestibility of these feeds, according to Van Soest (1967) and Cabral et al. (2008).

The "A" values obtained by the silage of soybean with brachiaria grass (Table 6) were close to those reported

Table 5 - Effective degradability of neutral detergent fiber (NDF) of silages of corn intercropped with brachiaria grass at different sowing arrangements

\begin{tabular}{lccccc}
\hline Silage & \multicolumn{5}{c}{ Parameter } \\
\cline { 2 - 6 } & B (\%) & U (\%) & L (h-1) & kd $\left(h^{-1}\right)$ & ED (\%) \\
\hline Corn + Bhand & 74.45 & 25.55 & 18.68 & 0.0215 & 34.52 \\
Corn + 2Brachrow & 76.53 & 23.47 & 5.9 & 0.0175 & 30.92 \\
Corn & 82.52 & 17.48 & 10.2 & 0.0155 & 30.60 \\
Brachiaria grass & 64.69 & 35.31 & 15.59 & 0.0235 & 35.61 \\
\hline
\end{tabular}

$\mathrm{B}$ = potentially digestible fraction; $\mathrm{U}=$ undegradable fraction; $\mathrm{L}=$ latency period; $k d$ = fractional rate of degradation; ED = effective degradation; Corn + Bhand = broadcast hand-sowing brachiaria grass in between the corn rows; Corn $+2 \mathrm{Brachrow}=$ seeding of two rows of brachiaria grass in between the corn rows.

Table 4 - Dry matter effective degradability of silages originated from the intercropping of corn and brachiaria grass established at different sowing arrangements

\begin{tabular}{lccccccc}
\hline Silage & \multicolumn{7}{c}{ Parameter } \\
\cline { 2 - 7 } & A (\%) & B (\%) & U (\%) & L $\left(\mathrm{h}^{-1}\right)$ & $\mathrm{kd}\left(\mathrm{h}^{-1}\right)$ & ED & pdDMED $(\%)$ \\
\hline Corn + Bhand & 32.6 & 46.77 & 20.63 & 2.95 & 0.0274 & 57.74 & 79.37 \\
Corn + 2Brachrow & 26.55 & 51.78 & 21.67 & 0.26 & 0.0217 & 50.70 & 78.33 \\
Corn & 30.3 & 51.93 & 17.77 & 0 & 0.025 & 56.75 & 82.23 \\
Brachiaria grass & 17.39 & 50.96 & 31.65 & 12 & 0.0233 & 45.44 & 68.35 \\
\hline
\end{tabular}

$\mathrm{A}=$ soluble fraction; $\mathrm{B}=$ potentially digestible fraction; $\mathrm{U}=$ undegradable fraction; $\mathrm{L}=$ latency period; $\mathrm{kd}=$ fractional rate of degradation; $\mathrm{ED}=$ effective degradation; pdDMED = potentially digestible dry matter effective degradation; Corn + Bhand = broadcast hand-sowing brachiaria grass in between the corn rows; Corn + 2Brachrow $=$ seeding of two rows of brachiaria grass in between the corn rows. 
Table 6 - Dry matter effective degradability of silages of soybean intercropped with brachiaria grass

\begin{tabular}{lccccccc}
\hline Silage & \multicolumn{7}{c}{ Parameter } \\
\cline { 2 - 7 } & A (\%) & B (\%) & U (\%) & L $\left(h^{-1}\right)$ & kd $\left(h^{-1}\right)$ & ED (\%) & pdDMED (\%) \\
\hline Brachiaria (R7) & 19.46 & 43.14 & 37.4 & 1.73 & 0.0237 & 43.43 & 62.6 \\
Brach + soy (R6) & 20.88 & 35.92 & 43.2 & 2.67 & 0.0287 & 45.88 & 56.8 \\
Brach + soy (R7) & 22.4 & 40.78 & 36.82 & 0 & 0.0304 & 51.45 & 63.18 \\
Brachiaria (R6) & 22.56 & 46.54 & 30.9 & 4.32 & 0.0326 & 52.89 & 69.1 \\
\hline
\end{tabular}

A = soluble fraction; $\mathrm{B}=$ potentially digestible fraction; $\mathrm{U}=$ undegradable fraction; $\mathrm{L}=$ latency period; $\mathrm{kd}=$ fractional rate of degradation; ED = effective degradation pdDMED = potentially digestible dry matter effective degradation; Brachiaria (R7) = brachiaria grass ensiled at the moment coinciding with the start of soybean grains maturation and $50 \%$ of yellowish foliation; Brach + soy $(R 6)=$ ensiling of brachiaria grass with soybean at complete soybean pod-fill; Brach + soy (R7) = ensiling of brachiaria grass with soybean at start of grains maturation and $50 \%$ of yellowish foliation; Brachiaria (R6) = ensiling of brachiaria grass at the moment coinciding with complete soybean pod-fill.

by the Tabela Brasileira de Composição de Alimentos (Valadares Filho et al., 2006) for brachiaria grass and soybean (19.23 and $18.47 \%$, respectively). However, the degradation rates in this study were lower than those found for brachiaria grass and soybean: 0.0438 and $0.556 \mathrm{~h}^{-1}$, respectively (Valadares Filho et al., 2006).

The low NDF degradation rates of silages of soybean with brachiaria grass (Table 7) can be attributed to the content of ether extract of soybean, which impairs fiber degradation. According to Palmquist \& Jenkins (1980), high contents of ether extract impair the rumen fermentation process due to the toxic effect to the microorganism and the physical hindering of the food particles, reducing their digestion.

There was rumen fill of all the materials originated from the intercropping of brachiaria grass with the corn and soybean cultivations (Table 8), which seems to be more linked to the feed passage rate, which depends on the physical (chewing during rumination) and microbial (degradation) actions, which determine the reduction of the size of the particles.
According to Van Soest (1994), rumen fill enables, jointly, evaluation of the effects of the interaction between passage and digestion kinetics on the capacity of filling the rumen compartment.

Table 7 - Effective degradability of neutral detergent fiber (NDF) of silages of soybean intercropped with brachiaria grass

\begin{tabular}{lccccc}
\hline Silage & \multicolumn{5}{c}{ Parameter } \\
\cline { 2 - 6 } & $\mathrm{B}(\%)$ & $\mathrm{U}(\%)$ & $\mathrm{L}\left(\mathrm{h}^{-1}\right)$ & $\mathrm{kd}\left(\mathrm{h}^{-1}\right)$ & $\mathrm{ED}(\%)$ \\
\hline Brachiaria (R7) & 56.23 & 43.77 & 2.66 & 0.022 & 29.82 \\
Brach + soy (R6) & 46.46 & 53.54 & 5.17 & 0.019 & 26.44 \\
Brach + soy (R7) & 50 & 50 & 2.62 & 0.021 & 29.85 \\
Brachiaria (R6) & 59.33 & 40.67 & 5.82 & 0.035 & 40.05 \\
\hline
\end{tabular}

$\mathrm{A}=$ soluble fraction; $\mathrm{B}=$ potentially digestible fraction; $\mathrm{U}=$ undegradable fraction; $\mathrm{L}=$ latency period; $\mathrm{kd}$ = fractional rate of degradation; $\mathrm{ED}=$ effective degradation; pdDMED = potentially digestible dry matter effective degradation; Brachiaria (R7) = brachiaria grass ensiled at the moment coinciding with the start of soybean grains maturation and $50 \%$ of yellowish foliation; Brach + soy (R6) ensiling of brachiaria grass with soybean at complete soybean pod-fill; Brach + soy (R7) = ensiling of brachiaria grass with soybean at start of grains maturation and $50 \%$ of yellowish foliation; Brachiaria (R6) = ensiling of brachiaria grass at the moment coinciding with complete soybean pod-fill.

Table 8 - Rumen fill estimates of silages of corn intercropped with brachiaria grass at different plant ages (experiment 1 ) and different sowing arrangements (experiment 2), and silages of soybean intercropped with brachiaria grass (experiment 3 )

\begin{tabular}{|c|c|c|c|c|c|c|c|}
\hline \multirow[t]{2}{*}{ Variable } & \multicolumn{7}{|c|}{ Parameter } \\
\hline & $\mathrm{B}$ & $\mathrm{U}$ & $\mathrm{Kd}\left(\mathrm{h}^{-1}\right)$ & $\operatorname{Ke}\left(h^{-1}\right)$ & $\mathrm{N}$ & $\lambda r\left(h^{-1}\right)$ & $\mathrm{RF}(\mathrm{h})$ \\
\hline & & \multicolumn{6}{|c|}{ Experiment 1} \\
\hline CEP & 0.738 & 0.262 & 0.0175 & 0.0506 & 3 & 0.2293 & 25.65 \\
\hline $20 \mathrm{D}$ & 0.6369 & 0.3631 & 0.0265 & 0.0506 & 3 & 0.2293 & 24.60 \\
\hline $40 \mathrm{D}$ & 0.7821 & 0.2179 & 0.011 & 0.0506 & 3 & 0.2293 & 27.51 \\
\hline $60 \mathrm{D}$ & 0.499 & 0.501 & 0.017 & 0.0506 & 3 & 0.2293 & 28.08 \\
\hline \multicolumn{8}{|c|}{ Experiment 2} \\
\hline $\mathrm{C}+$ Bhand & 0.7445 & 0.2555 & 0.0215 & 0.0506 & 3 & 0.2293 & 24.45 \\
\hline $\mathrm{C}+2 \mathrm{Brow}$ & 0.7653 & 0.2347 & 0.0175 & 0.0506 & 3 & 0.2293 & 25.38 \\
\hline Corn & 0.8252 & 0.1748 & 0.0155 & 0.0506 & 3 & 0.2293 & 25.49 \\
\hline Brachiaria grass & 0.6469 & 0.3531 & 0.0235 & 0.0345 & 3 & 0.2351 & 29.96 \\
\hline \multicolumn{8}{|c|}{ Experiment 3} \\
\hline Brach (R7) & 0.5623 & 0.4377 & 0.022 & 0.0345 & 3 & 0.2351 & 31.90 \\
\hline Brach + Soybean (R6) & 0.4646 & 0.5354 & 0.019 & 0.0272 & 3 & 0.169 & 43.18 \\
\hline Brach + Soybean (R7) & 0.5 & 0.5 & 0.021 & 0.0272 & 3 & 0.169 & 41.61 \\
\hline Brach (R6) & 0.5933 & 0.4067 & 0.035 & 0.0345 & 3 & 0.2351 & 28.38 \\
\hline
\end{tabular}

$\mathrm{B}$ = potentially digestible fraction; $\mathrm{U}=$ undegradable fraction; $\mathrm{kd}=$ fractional rate of degradation; ke = rate of escape from the pool of escapable particles marked with rumen indicator by the reticulo-omasal orifice; $\mathrm{N}=$ order of time dependence; $\lambda \mathrm{r}=$ rate of transfer of the particles marked by the raft indicator to the pool of escapable particles, $\mathrm{RF}=$ rumen fill; $\mathrm{CEP}=$ corn ensiling point; $20 \mathrm{D}=20$ days after corn ensiling point; $40 \mathrm{D}=40$ days after corn ensiling point; $60 \mathrm{D}=60$ days after corn ensiling point $\mathrm{C}+$ Bhand $=$ broadcast hand-sowing brachiaria grass in between the corn rows; $\mathrm{C}+2 \mathrm{Brow}=$ seeding of two rows of brachiaria grass in between the corn rows. 


\section{Conclusions}

Silages of brachiaria grass intercropped with corn and/or soybean are feeds of low nutritive value, due to their low NDF degradation rate and passage rate, causing rumen fill and thus, possible low intake and lower animal performance

\section{References}

CABRAL, L.S.; VALADARES FILHO, S.C.; DETMANN, E. et al. Avaliação de indicadores na estimação da excreção fecal e da digestibilidade em ruminates. Revista Brasileira de Saúde e Produção Animal, v.9, n.1, p.29-34, 2008.

CARVAlHO, G.G.P.; PIRES, A.J.V.; Veloso, C.M. et al. Degradabilidade ruminal do feno de forrageiras tropicais. Revista Brasileira de Agrociência, v.12, n.1 p.81-85, 2006.

CASTRO, C.R.RT.; GARCIA, R.; CARVALHO, M.M. et al. Produção forrageira de gramíneas cultivadas sob luminosidade reduzida. Revista brasileira de Zootecnia, v.28, n.5, p.919-927, 1999.

CHERNEY, D.J.R.; SICILIANO-JONES, J.; PELL, A.N. Forage in vitro dry matter digestibility as influenced by fiber source in the donor cow diet. Journal of Animal Science, v.71, p.1335-1338, 1993.

ELLIS, W.C.; MAHLOOJI, M.; LASCANO, C.E. et al. Effects of size in ingestively masticated fragments of plant tissue on kinetics of digestion of NDF. Journal of Animal Science, v.83, p.1602-1615, 2005.

ELLIS, W.C.; BEEVER, K.C. Methods for binding rare earths to specific feed particles. In: KENNEDY, C.M.P. (Ed.) Techniques in particles size analysis of feed and digest in ruminants. Edmonton: Canadian Society of Animal Science, 1984. p.154-165.

FEHR, W.R.; CAVINESS, C.E. Stage of soybean development. Iowa State University,_Iowa, 1977. 12p. (Special Report 80).

FERREIRA, L.A.M.; FONTES, C.M.G.A.; FERNANDES, T.H. A fibra em nutrição animal. Revista Portuguesa de Ciências Veterinárias, v.94, n.531, p.119-130, 1999.

GROVUM, W.L.; WILLIAMS, V.J. Rate of passage of digesta in sheep. 4. Passage of marker through the alimentary tract and the biological relevance of rate-constants derived from the changes in concentration of marker in feces. British Journal Nutrition, v.30, n.3, p.313-329, 1973.

HARTNELL, G.F.; SATTER, L.D. Extent of particulate marker (Samarium, Lanthanum and Cerium) movement from one digesta particle to another. Journal of Animal Science, v.48, n.375, 1979.

HENRIQUES, L.T.; COELHO DA SILVA, J.F.; VÁSQUEZ, H.M. et al. Efeito do acipin sobre a degradabilidade e taxa de passagem de silagens de capim elefante e de milho em bovinos mestiços Holandês x Zebu. In: REUNIÃO ANUAL DA SOCIEDADE BRASILEIRA DE ZOOTECNIA, 38., 2001, Piracicaba. Anais... Piracicaba: Sonopress, 2001. p.1321-1322. (CD-ROM).

HUNTINGTON, J.A.; GIVENS, D.I. The in situ technique for studying the rumen degradation of feeds: a review of the procedure. Nutricional Abstracts and Reviews. Series B, v.65, n.2, p.63-93, 1995.

KEPHART, K.D.; BUXTON, D.R.; TAYLOR, S.E. Growth of C3 and C4 perennial grasses to shade. Crop Science, v.33, p.831-837, 1993.

KIRKPATRICK, B.K.; KENNELLY, J.J. In situ degradability of protein and dry matter from single protein sources and from a total diet. Journal of Animal Science, v.65, p.567-576, 1987.

LEONEL, F.P.; PEREIRA, J.C.; COSTA, M.G. et al. Consórcio capim-braquiária e milho: produtividade das culturas e características qualitativas das silagens feitas com plantas em diferentes idades. Revista Brasileira Zootecnia, v.37, n.12, p.2233-2242, 2008.
LEONEL, F.P. Consórcio capim-braquiária com milho ou soja: produção e composição químico-bromatológica das silagens. 2007. 149f. Tese (Doutorado em Zootecnia) - Universidade Federal de Viçosa, Viçosa, MG.

LIRA, V.M.C.; PEREIRA, J.C.; VIEIRA, R.A.M. et al. Avaliação de marcadores e modelos matemáticos para estudos das cinéticas de trânsito e de degradação ruminal em novilhos matidos em pastegem de capim-braquiária (Braquiária decumbens Stapf.). Revista Brasileira de Zootecnia, v.35, n.3, p.902-913, 2006.

MARTINS, A.S.; VIEIRA, P.F.; BERCHIELLI, T.T. et al. Taxa de passagem e parâmetros ruminais em bovinos suplementados com enzimas fibrolíticas. Revista Brasileira de Zootecnia, v.35, n.3, p.1186-1193, 2006.

MASUDA, Y. Comparisons of in vitro dry matter digestibility of forage oats grown under different temperatures and light intensities. Journal of the Faculty of Agriculture, v.21, p.17-24, 1977.

MATIS, J.H. Gamma time-dependency in Blaxter's compartmental model. Biometrics, v.28, n.2, p.597-602, 1972.

MEHREZ, A.Z.; ØRSKOV, E.R. A study of the artificial fibre bag technique for determining the digestibility of feeds in the rumen. Journal of Agriculture Science, v.88, n.3, p.645-650, 1977.

MERTENS, D.R. Using fiber and carbohydrate analyses to formulate dairy rations. In: INFORMATIONAL CONFERENCE WITH DAIRY AND FORAGE INDUSTRIES, 1996, Wisconsin, 1996. Proceedings... Wisconsin: [s.ed.], 1996. p.81-92.

MERTENS, D.R.; LOFTEN, J.R. The effect of starch on forage fiber digestion kinetics in vitro. Journal of Dairy Science, v.36, p.1437-1446, 1980

MOORE, J.A.; POND, K.R.; POORE, M.H. et al. Influence of model and marker on digesta kinetic estimates for sheep. Journal of Animal Science, v.70, n.12, p.3528-3540, 1992.

NOCEK, J.E. Evaluation of specifi c variables affecting in situ estimates of ruminal dry matter and protein digestion. Journal of Animal Science, v.60, n.5, p.1347-1358, 1985.

PACIULLO, D.S.C.; CARVALHO, C.A.B.; AROEIRA, L.J.M. et al. Morfofisiologia e valor nutritivo do capim-braquiária sob sombreamento natural e a pleno sol. Pesquisa Agropecuária Brasileira, v.42, n.4, p.573-579, 2007.

PALMQUIST, D.L.; JENKINS, T.C. Fat in lactation rations: Review. Journal of Dairy Science, v.63, n.1, p.1, 1980.

RIGUEIRA, J.P.S. Silagem de soja na alimentação de bovinos de corte. 2007. 6fp. Dissertação (Mestrado em Zootecnia) Universidade Federal de Viçosa, Viçosa, MG.

RODRIGUES, A.L.P.; SAMPAIO, I.B.M.; CARNEIRO, J.C. et al. Degradabilidade in situ da matéria seca de forrageiras tropicais obtidas em diferentes épocas de corte. Arquivo Brasileiro de Medicina Veterinária e Zootecnia, v.56, n.5, p.658-664, 2004.

RODRIGUES, M.T.; VIEIRA, R.A.M. Metodologias aplicadas ao fracionamento de alimentos. In: BERCHIELLI, T.T.; PIRES, A.V.; OLIVEIRA, S.G. (Ed.) Nutrição de Ruminantes. 1. ed. Jaboticabal: FUNEP, 2006. p.25-55.

SAMARAKOON, S.P.; WILSON, J.R.; SHELTON, H.M. Growth, morphology and nutritive quality of shaded Stenotaphrum secundatum, Axonopus compressus, and Pennisetum clandestinum. Journal of Agricultural Science, v.114, p.161-169, 1990.

SHAVER, R.D.; NYRTES, J.; SATTER, L.D. et al. Influence od feed intake, forage physical form and forage fiber content on particle size of masticated forage, ruminal digesta and feces of dairy cows. Journal of Dairy Science, v.71, p.1566-1572, 1988.

SILVA, M.E.T.; WASCZCZYNSKYJ, N.; SOCCOL, C.R. et al. Degradação ruminal da fração fibra de silagens de milho sem espigas com cana-de-açúcar e bagaço de mandioca. Acta Animal Scientiarum, v.28, n.4, p.431-436, 2006.

SOARES, J.P. Fatores limitantes do consumo de capimelefante cv. Napier utilizando vacas leiteiras confinadas. 2002. 110f. Tese (Doutorado em Zootecnia) - Universidade Estadual Paulista, Jaboticabal. 
STATISTICAL ANALYSIS SYSTEM - SAS, SAS/STAT user's guide (Release 9.1), Cary: 1999. (CD-ROM).

UDÉN, P.; COLUCCI, E.P.; VAN SOEST, P.J., Investigation of chromium, cerium and cobalt as markers in digesta, Rate of passage studies. Journal of the Science of Food Agriculture, v.31, n.7, p.625-632, 1980.

VALADARES FILHO, S.C.; MAGALHÃES, K.A.; ROCHA JUNIOR, V.R. et al. Tabela brasileira de composição de alimentos para bovinos. 2.ed. Viçosa, MG: Universidade Federal de Viçosa, 2006. 329p.

VAN SOEST, P.J. Development of comprehensive system of feed analyses and application to forages. Journal of Animal Science, v.26, p.119-131, 1967.
VAN SOEST, P.J. Nutritional ecology of the ruminant. 2.ed. Ithaca: Cornell University Press, 1994. 476p.

VIEIRA, R.A.M.; TEDESCHI, L.O.; CANNAS, A. A generalized compartmental model to estimate the fibre mass in the ruminoreticulum: 2. Integrating digestion and passage. Journal of Theoretical Biology, v.255, p.357-368, 2008.

WALDO, D.R. Effect of forage quality on intake and forageconcentrate interactions. Journal of Dairy Science, v.69, n.4, p.617-631, 1986.

WILLIAMS, C.H.; DAVID, D.J.; IISMAA, O. The determination of chromic oxide in feces samples by atomic absorption spectrophotometry. Journal of Agriculture Science, v.59, n.3, p.381-385, 1962. 